\title{
DEFENSORIA PÚBLICA VERSUS SERVIÇO SOCIAL: ANÁLISE DO PROGRAMA PAI LEGAL COMO INSTRUMENTO DE INCLUSÃO
}

\section{FAMILIAR}

\section{ARTIGO ORIGINAL}

ALMEIDA, Elizabeth dos Anjos Brasil ${ }^{1}$

ANDRADE, Maria Gorete da Silva²

GERALDO, Valéria do Socorro Antonio dos Santos ${ }^{3}$

PERALTA, Vanderlena Ribeiro Rocha ${ }^{4}$

BARACHO, Gessyca Anne da Silva ${ }^{5}$

ALMEIDA, Elizabeth dos Anjos Brasil. Et al. Defensoria pública versus serviço social: análise do Programa Pai legal como instrumento de inclusão familiar. Revista Científica Multidisciplinar Núcleo do Conhecimento. Ano 04, Ed. 07, Vol. 11, pp. 21-39. Julho de 2019. ISSN: 2448-0959

1 Assistente Social, Pós-Graduação Especialista em Gestão e Planejamento de Políticas Públicas em Serviço Social. Graduação: Bacharel em Serviço Social.

2 Assistente Social, Pós-Graduação Especialista em Gestão e Planejamento de Políticas Públicas em Serviço Social. Graduação: Bacharel em Serviço Social.

${ }^{3}$ Assistente Social, Pós-Graduação Especialista em Gestão e Planejamento de Políticas Públicas em Serviço Social. Graduação: Bacharel em Serviço Social.

${ }^{4}$ Assistente Social, Pós-Graduação Especialista em Gestão e Planejamento de Políticas Públicas em Serviço Social. Graduação: Bacharel em Serviço Social.

${ }^{5}$ Assistente Social, Mestre em Serviço Social. 


\section{RESUMO}

Este artigo apresentou como objetivo a análise do Programa Pai Legal como proposta de inclusão sócio familiar de crianças e adolescentes em Belém-PA. Neste sentido, foi realizado o debate no campo dos direitos sociais no Brasil, considerando a legislação, código civil, o ECA e o Serviço Social. O estudo foi orientado pela teoria social crítica, a qual demonstra que a realidade social é resultado exclusivo da ação humana. Sendo assim, este estudo foi baseado na observação do trabalho da equipe psicossocial do NAEFA/Psicossocial e também a partir de pesquisa qualitativa mediante a observação empírica do citado programa, além da realização de estudo bibliográfico de renomados autores que já se debruçaram sobre o presente tema. Desta maneira, apesar das ações da Defensoria Pública, direcionados a este segmento, seu limite permanece no campo da proposta de "inclusão" sócio familiar, ou seja, distanciado do viés que imprime garantida, em sua totalidade, a transformação da realidade social das famílias, concepção esta que confere ao assistente social, um dos poucos profissionais que ainda expressam concepções emancipatórias para a humanidade.

Palavras-Chave: Defensoria Pública, Serviço Social, Programa Pai Legal.

\section{INTRODUÇÃO}

Este artigo abordará a questão da atuação da Defensoria Pública e do Serviço Social e realizará uma análise do Programa Pai Legal como instrumento de inclusão sócio familiar em Belém-Pa. É importante informar que o referido Programa é um projeto de efetivação e garantia de cidadania plena de crianças e adolescentes, pois busca o reconhecimento voluntário de paternidade, cumprindo o direito estabelecido pelo art. 1.609 do Código Civil. Neste sentido, Oliveira (1995) declara que todas as crianças têm direito de saber sua origem paternal.

A proposta surgiu a partir da experiência de uma das autoras deste artigo, a qual atuou junto ao núcleo de atendimento especializado da família - NAEFA, na área psicossocial da Defensoria Pública do Estado do Pará. Neste sentido, o objetivo deste 
estudo será analisar o Programa Pai Legal a partir da proposta de inclusão sócio familiar de crianças e adolescentes em Belém-PA.

Para tanto, se verificará as propostas de inclusão sócio familiar para as crianças e adolescentes, apresentadas no Programa Pai Legal em Belém e se examinará as particularidades do serviço social na Defensoria Pública junto ao Programa Pai Legal. Sendo assim, a proposta apresentará a seguinte pergunta de pesquisa: Como o Programa Pai Legal instrumentaliza a inclusão sócio familiar de crianças e adolescentes em Belém-PA?

Ressalta-se que, esta pesquisa será orientada a partir da teoria social crítica, a qual demonstra que a realidade social é resultado exclusivo da ação humana, pois, neste estudo se trabalhará com a observação do trabalho da equipe psicossocial do NAEFA/Psicossocial e também a partir de pesquisa qualitativa mediante a observação empírica do citado programa, além da realização de estudo bibliográfico de autores que já se debruçaram sobre a presente temática.

Neste sentido, inicialmente se fará um breve histórico do serviço social no Brasil; em seguida, se abordará a legislação, código civil o ECA, os direitos sociais dos cidadãos e a Defensoria Pública no Brasil; em terceiro, a pesquisa irá examinar de forma mais detalhada o Programa Pai Legal em Belém e, finalmente, se analisará a relevância do assistente social e sua atuação profissional dentro da temática deste trabalho.

\section{MATERIAIS E MÉTODO}

O presente estudo analisou a questão da atuação da Defensoria Pública e do Serviço Social ao realizar um exame do Programa Pai Legal como instrumento de inclusão sócio familiar em Belém-Pa. Para tanto, em relação a sua natureza foi feita Uma Pesquisa Básica, a qual objetivou gerar conhecimentos novos, que fossem efetivamente úteis para o avanço da ciência, mesmo sem aplicação prática prevista, pois envolveu verdades e interesses universais. 
Quanto à abordagem do problema esta é uma Pesquisa Qualitativa. Visto que, considera que há uma relação dinâmica entre o mundo real e o sujeito, isto é, um vínculo indissociável entre o mundo objetivo e a subjetividade do sujeito que não pode ser traduzido em números. Pois, a interpretação dos fenômenos e a atribuição de significados são básicas no processo de pesquisa qualitativa (ACACIO, 2017).

Quanto aos objetivos esta é uma Pesquisa Explicativa. Já que, visa identificar os fatores que determinam ou contribuem para a ocorrência dos fenômenos e aprofunda o conhecimento da realidade do Programa Pai Legal como instrumento de inclusão sócio familiar em Belém-Pa.

Quanto aos procedimentos técnicos esta é uma Pesquisa Bibliográfica, pois fora elaborada a partir de material já publicado, constituído principalmente de livros, artigos de periódicos e com material de sites acadêmicos de reconhecimento seguro disponibilizados na Internet.

Cabe enfatizar que, o estudo foi orientado pela teoria social crítica, a qual demonstra que a realidade social é resultado exclusivo da ação humana. Para tanto, este estudo foi baseado na observação do trabalho da equipe psicossocial do NAEFA/Psicossocial em Belém do Pará.

\section{FUNDAMENTAÇÃO TEÓRICA}

\subsection{O DEBATE NO CAMPO DOS DIREITOS SOCIAIS NO BRASIL}

A Constituição Federal em seu título I, no art. $1^{\circ}$ inciso-III, refere a respeito de um princípio: a dignidade da pessoa humana; 0 art. $3^{\circ} \mathrm{em}$ seu inciso-I expõe que: "construir uma sociedade livre, justa e solidaria;" como também o inciso IV, dita que deve "promover o bem estar de todos, sem preconceitos de origem, raça, cor, idade e quaisquer outras formas de discriminação." são princípios fundamentais que devem ser efetivados a todos sem exceção, pois os mesmos foram ratificados na Carta Magna/88. Desta forma, Simões $(2014$, p. 191, 192) assevera que: 
O direito à convivência familiar, por isso, supera o mero rendimento per capta, para se fixar no âmbito do núcleo sócio afetivo, não somente por laços consanguíneos, como também de aliança ou afinidade, em torno das relações de geração e de gênero. Por isso, a intervenção do Poder Público em suas relações primárias somente é aceitável quando constatada a sua desagregação social, total ou parcial [...].

O conceito sobre a dignidade da pessoa humana é percebido por um ponto de vista complexo, desenvolvido em uma diversidade de valores existentes na sociedade, em um aspecto jurídico, no qual declara Sarlet (2007):

"Temos por dignidade da pessoa humana a qualidade intrínseca e distintiva de cada ser humano que o faz merecedor do mesmo respeito e consideração por parte do Estado e da comunidade, implicando, neste sentido, um complexo de direitos e deveres fundamentais que asseguram a pessoa tanto contra todo e qualquer ato de cunho degradante e desumano, como venham a the garantir as condições existenciais mínimas para uma vida saudável, além de proporcionar e promover sua participação ativa e corresponsável nos destinos da própria existência e da vida em comunhão com os demais seres humanos" (SARLET, 2007, p.62).

Ressaltando ainda, como forma de garantir e regular efetivamente ao exercício do direito de filiação, foi sancionada a lei $n^{\circ}$ 8.560, de 29 de dezembro de 1992, que efetiva legalmente a investigação de paternidade dos filhos havidos fora do casamento. Desta maneira, fica incontestável que o direito a filiação é um direito fundamental que assegura aos sujeitos de direitos o pleno acesso e garantia ao princípio da dignidade humana, à vida, à convivência familiar. Sobre este aspecto, Lima (2012):

O Brasil tem uma Constituição ímpar em sua história, uma Carta que recepcionou a Declaração Universal dos Direitos Humanos, mas, cada brasileiro tem a obrigação moral de ser um vigiar, pois, um País que 
declara estar fundado na dignidade da pessoa humana, deve a todo instante, considerar se cada cidadão é tomado como fim em si mesmo ou como instrumento, sendo meio para outros objetivos (Lima, 2012).

Desta forma, seguindo nesta linha de raciocínio, o Estatuto da criança e do adolescente - ECA refere que na lei $n^{\circ}$ 8.069, de julho de 1990, em art. 26 que: "os filhos havidos fora do casamento poderão ser reconhecidos pelos pais, conjunta ou separadamente, no próprio termo de nascimento, por testamento público, qualquer que seja a origem de filiação". O ECA declara em seu art. 18 que "É dever de todos velar pela dignidade da criança e do adolescente, pondo a salvo de qualquer tratamento desumano, violento, aterrorizante, vexatório ou constrangedor".

Sendo assim, a realidade sinaliza que o abuso emocional manifestado por parte de um dos genitores, tem levado o público infanto/juvenil à alienação parenta[[6] essas condutas colaboram negativamente para um convívio saudável e harmônico entre criança, adolescente e seu genitor. Prejudicando e dificultando em diferentes características seu desenvolvimento afetivo, intelectual, físico e moral.

Entre os princípios fundamentais da Constituição Federal de 1988 encontra-se o Princípio da Dignidade Humana, o qual declara que todas as crianças têm direito de saber sua origem paternal. Desta mesma maneira, o reconhecimento de paternidade é a mais eficiente proteção da pessoa e do filho.

A partir desta ideia passa-se também a reconhecer que ao ser humano não se pode atribuir valor ou preço, pois o ser humano em virtude tão somente de sua condição meramente biológica, gênero humano, e independentemente de qualquer outra circunstância, é possuidor de dignidade, isso de via unilateral, sendo então segundo a concepção do direito moderno "igual" aos seus demais diante da lei (LIMA, 2012).

A reunião num coletivo de individualidades diferentes precisa assentar no respeito à diversidade dos interesses isolados. Cria-se assim uma nova dimensão social, em que a diversidade se apresenta numa prática política que relativiza as arestas mais ásperas do confronto de 
interesses, na medida em que as consciências se transformam, e com elas os próprios objetivos individuais (MAAR, 2006, p. 24).

Segundo os autores, compreendemos que o direito de investigar a paternidade através do exame de DNA, tem como objetivo estabelecer aos indivíduos sua origem genética, identificar os laços afetivos existentes e as relações de parentesco que poderão ser estreitadas, aproximadas. Contudo, não contemplamos evidentemente que tais relações serão de fato vivenciadas por trocas mútuas de afeto, ou seja, não há um determinante que garanta efetivamente a real convivência e o fortalecimento dos laços afetivos entre os membros em uma determinada configuração familiar.

\subsection{DEFENSORIA PÚBLICA E O CAMPO DE AÇÃO DO SERVIÇO SOCIAL}

A Defensoria Pública enquanto instituição comprometida com a Política Nacional dos Direitos humanos implantou no ano de 2005 o PROGRAMA PAI LEGAL para prestar serviço de reconhecimento paterno espontâneo ou por meio de teste de DNA de forma gratuita e não judicial. O programa Pai Legal tem como objetivo garantir a cidadania plena da criança ou do adolescente com o reconhecimento de paternidade. Este é um direito estabelecido como um princípio da dignidade humana (Constituição Federal/88), efetivo no Art. 27 do ECA.

Neste sentido, THULER, declara que "O reconhecimento paterno pode proporcionar o restabelecimento da afetividade familiar e da sociedade e promove sobremaneira a paz social, pois nesse ato também estão sendo incutidos valores morais e sociais." (THURLER, 2004). Seguindo nesta mesma linha de raciocínio, aprende-se que o reconhecimento de paternidade oportuniza a proteção à sociedade, ou seja, às famílias de crianças e adolescentes que se encontram sem paternidade estabelecida, ou seja, sem referências biológicas paternas, são apenas registradas com o nome materno.

Desta forma, compreendemos que a igualdade no direito da filiação está assegurada conforme expõe ECA no art. 20, assim como no art. 1.596, do Código Civil, 
determinam, proporcionam, concedem, os mesmos direitos e qualificações entre filhos, sendo proibidas quaisquer designações discriminatórias relativas à filiação. Desta maneira, entende-se que a Defensoria promove a integração sócio familiar deste seguimento, respaldado no ECA que em seu art. 27 assegura ao público infantojuvenil, o reconhecimento do estado de filiação.

Em se tratando do Protagonismo da Defensoria Pública no Estado Democrático de Direito, de acordo com ordenamento o Manual de Mediação para a Defensoria (2014), expõe:

O artigo $1^{\circ}$ da LC 80/90 determina que "a Defensoria Pública é instituição permanente, essencial à função jurisdicional do Estado, incumbindo-lhe, como por expressão e instrumento do regime democrático, fundamentalmente, a orientação jurídica, a promoção dos direitos humanos e a defesa, em todos os graus, judicial e extrajudicial, dos direitos individuais e coletivos na forma do inciso LXXIV do art. $5^{\circ}$ da Constituição Federal". [...] O projeto normativo é de construção de um Estado que não se limite em acusar os seus cidadãos, mas que efetivamente os enxergue, acolha, entenda, proteja e defenda. (ROSENBLATT [et al.], 2014, p. 32).

A Defensoria Pública do Estado do Pará surgiu em 1983, para promover o serviço de assistência judiciária antes realizada pelo Ministério Público do Estado. No mesmo ano, a instituição foi regulamentada pela Lei Complementar no 013 de 18 de junho de 1993, tendo como objetivo proporcionar amplo acesso à justiça aos cidadãos hipossuficientes do Pará.

Três anos depois, o Governo do Estado promulgou o decreto nํ⒌494 de 27 de junho de 1988, reestruturando administrativamente a Procuradoria Geral do Estado e a defensoria Pública. $O$ mesmo decreto criou funções gratificadas, desvinculou a instituição da Procuradoria e a subordinou ao chefe de poder Executivo. 
Em fevereiro de 2006, foi publicada a lei Complementar № 054 que reestruturou e regulamentou a Defensoria Pública, estabelecendo atribuições e o funcionamento de seus órgãos e unidades, em especial a formação de lista tríplice após a eleição interna para a escolha do Defensor Geral, cria o Conselho Superior da defensoria Pública e restringe a ocupação da maioria dos cargos em comissão aos integrantes da carreira, a criação de gratificações, além de dispor sobre a Carreira de seus membros e a iniciativa para a criação de cargos.

A Lei Estadual 7022, de 24 de julho de 2007 passa a vincular a Defensoria Pública do Estado diretamente ao Gabinete da Governadoria do Estado, deixando de ser subsecretaria da secretaria especial de Defesa Social. Como também, a Lei Complementar 067/08 - Altera A Lei Orgânica Estadual, concedendo reajuste aos servidores do órgão de $70 \%$ para $100 \%$ no percentual da gratificação de dedicação exclusiva incidente sobre o vencimento base dos membros da carreira.

A partir do ano de 2008, a Defensoria tem assegurada sua autonomia orçamentária e financeira prevista na Constituição Federal, através das Leis de Planejamento Tributário do Estado Plano Plurianual (PPA), Lei de Diretrizes Orçamentárias (LDO) e Lei Orçamentária Anual (LOA). Hoje é uma instituição em fortalecimento e estruturação, que conta com 260 defensores públicos, 229 servidores e 213 estagiários, totalizando 702 agentes, e atende à população de 102 comarcas paraenses.

Ao longo desses anos, vem desempenhando um papel relevante na garantia dos cidadãos mais necessitados e na afirmação da dignidade humana. Nesse sentido, "O valor da dignidade é considerado absoluto, visto inexistir no texto constitucional qualquer hipótese em que possa ser restringido" (Simões, p, 61. 2014). Neste contexto, podemos dizer que os direitos humanos fundamentais devam ser norteados para a visibilidade e ampliação da dignidade humana. Assim, Simões (2014, p. 79) declara que:

"Os direitos humanos fundamentais passam a ser dirigidos para a proteção da dignidade, valor supremo que atrai o conteúdo de todos os 
direitos fundamentais, inclusive o direito à vida, posto que nem mesmo a morte das pessoas elimina seu tratamento dignitário".

Conforme se observa no trecho destacado, este é um princípio construído pela história da humanidade, e o mesmo princípio tem buscado como bem maior proteger o ser humano contra qualquer forma de desprezo, discriminação e exclusão; observando a declaração de Kant: "Mas o homem não é uma coisa" (KANT, 2008, p.60). Sendo o homem um ser, Ihe é assegurado pela Constituição Federal/1988, suas garantias legais de proteção, a qual Lima afirma em sua obra, O princípio da dignidade da pessoa humana nas constituições do Brasil, a qual refere:

Logo é todo ser humano titular de direitos, ainda que o mesmo não os defenda ou não os reconheça em si, devendo estes direitos serem reconhecidos e respeitados por nós seus semelhantes e pelo estado, pois, cabe a este último a tarefa de garantir o respeito das liberdades civis, ou seja, o respeito pelos direitos humanos e pelas liberdades fundamentais, o qual se faz através do estabelecimento de uma proteção jurídica Lima (2012).

O Estatuto da Criança e do Adolescente - ECA, em seu artigo 27 expõe que o reconhecimento do estado de filiação é um direito personalíssimo, sendo de extrema necessidade garanti-lo. Este artigo reconhece os direitos já garantidos na Constituição Federal, visando sanar uma lacuna normativa em decorrência de conflitos existentes no âmbito do Direito de Família que assegure a proteção à criança e ao adolescente, à margem do ordenamento jurídico em relação ao histórico biológico da pessoa do filho.

Deste modo, a Constituição Federal de 1988, refere que a família tem proteção especial, pois esta é a base do sistema organizacional da sociedade, mas também é posta como um dos organismos sociais e jurídicos existentes que merecem maior atenção, por apresentar relações de conflitos e interesses divergentes. Desta maneira, para uma maior compreensão a respeito do princípio da Dignidade da Pessoa Humana, a Carta Magna como um dos princípios fundamentais em seu artigo $1^{\circ} \mathrm{e}$ inciso III, cita: "a dignidade da pessoa humana". 
Para tanto, de acordo com o exposto, o conceituado jurista Ingo Wolfgang Sartet, ressalta que a inserção do princípio supracitado como fundamento do Estado Democrático de Direito tem relevante importância, posto que o referido fato balize o sistema jurídico, nos diferentes campos do Direito. Desta forma, Sarlet refere: "a constituição consagrou o princípio e, considerando a sua eminência, proclamou-o entre os princípios fundamentais, atribuindo-lhe o valor supremo de alicerce da ordem jurídica democrática" (SARLET, 2003, p. 115).

Neste sentido, buscamos analisar a intervenção do assistente social, considerando aspectos da sua história particularizada na realidade brasileira, onde 0 desenvolvimento do serviço social trouxe, em sua gênese, ações conservadoras, tradicionais, com princípios, valores e posturas norteadas pela doutrina social da igreja católica, referenciados por ações filantrópicas, de caridade e a ajuda. No primeiro momento o Movimento de Reconceituação não contemplou estratégias concretas de transformação da realidade social dos sujeitos sociais; contudo, este movimento norteou o rompimento das ações filantrópicas, assistencialistas, caritativas e fragmentadas.

[...] surgiram elaborações teórico-práticas que se desdobraram e romperam a hegemonia do conservadorismo na profissão, possibilitando, inclusive, a construção de um referencial ético que não mais preconizou valores assentados em interesses individuais ou de grupos particulares (FORTI, 2013, p. 103).

No Brasil o Serviço Social passou por diversas alterações e transformações, desenvolveu seu processo de renovação a partir dos anos 1964 até meados da década de 1980; neste sentido, buscou romper com o caráter meramente executivo, com o conservadorismo tradicional, cultura profissional acrítica, posturas reacionárias, e se propõe em elaborar um conjunto de instrumentos legais, normativos e políticos que legitimam, norteiam e conduzem suas práticas profissionais, as quais perpassem por uma atuação comprometida com a produção de um conhecimento crítico, reflexivo e propositivo da realidade das demandas sociais, como ressalta Ortiz (2010): 
Assim, a Reconceituação questionava o papel dos Assistentes Sociais no processo de superação da condição de subdesenvolvimento dos países latino-americanos em um cenário no qual os projetos desenvolvimentistas nacionais de corte democrático-liberal davam claros sinais de ineficiência e incompatibilidade com os reais interesses e necessidades da população (ORTIZ, 2010, p. 162).

A materialização do projeto ético-político profissional assentado nos princípios e valores preconizados no Código de Ética Profissional de 1993, como também, à lei 8.662 de 1993 que regulamenta a profissão de assistente social e das Diretrizes Curriculares da ABESPP de 1996. Desta forma, NETO (2001) ressalta a importância do Projeto Ético Político em conduzir o fazer profissional e sua autoimagem.

Os projetos profissionais apresentam a autoimagem de uma profissão, elegem os valores que a legitimam socialmente, delimitam e priorizam seus objetivos e funções, formulam os requisitos (teóricos, práticos e institucionais) para o seu exercício, prescrevem normas para o comportamento dos profissionais e estabelecem as bases das suas relações com os usuários de seus serviços, com as outras profissões e com as organizações e instituições sociais privadas e públicas (inclusive - Estado, a que cabe o reconhecimento jurídico dos estatutos profissionais). (NETO 2001, p. 4).

Neste sentido, o serviço social desde sua gênese tem em seu bojo enquanto centralidade o segmento família. Segundo Vignoli (2007) a família tornou-se o elemento central da intervenção das políticas de assistência social, enquanto alvo privilegiado dos programas sociais, pois à medida que o Estado restringe sua participação na atenção de questões de determinados segmentos, a família é chamada a preencher este espaço.

Nestes espaços institucionais as políticas públicas apresentam-se de forma peculiar são fragmentadas, seletivas e focalizadas, atendem aos interesses dos gestores estatais; assim, o que se visualiza são ações descontinuadas, o sucateamento da 
máquina pública, os mínimos sociais e a precarização de serviços; em contrapartida todos os esforços são direcionados para a hegemonia do Estado, o fortalecimento do privado em relação à circulação, acumulação e financeirização do capital.

\subsection{ANÁLISE DO PROGRAMA PAI LEGAL COMO INSTRUMENTO DE INCLUSÃO SÓCIO FAMILIAR EM BELÉM-PA}

A capital do Estado do Pará, Belém, ao norte faz limite com a Baía de Marajó, ao leste com o município de Ananindeua, ao oeste com a Baía do Guajará e ao sul, com o Rio Guamá. A cidade possui uma população estimada de 1.452 .275 habitantes, sendo que em torno de $57 \%$ são mulheres e $43 \%$ de homens. O Programa Pai Legal, como já mencionado é um projeto de efetivação e garantia de uma cidadania plena de crianças e adolescentes e, que o reconhecimento voluntário de paternidade é um direito estabelecido pelo art. 1.609 do Código Civil.

Através do Programa Pai Legal e mediante conciliações extrajudiciais realizadas por uma equipe interdisciplinar, com o objetivo de garantir a cidadania plena da criança e do adolescente com o reconhecimento de paternidade. Este é um direito estabelecido como um princípio da dignidade humana (CONSTITUIÇÃO FEDERAL/1988), efetivo no Atr. 27 do ECA, que cita:

"O reconhecimento do estado de filiação é direito personalíssimo, indisponível e imprescritível, podendo ser exercitado contra os pais ou seus herdeiros, sem qualquer restrição, observando o segredo de justiça."

Desta forma, buscando minimizar as divergências, exclusões no âmbito sócio familiar e, o constrangimento de crianças e adolescentes que não possuem pai registral, o Programa Pai legal apresenta o reconhecimento de paternidade, como instrumento de inclusão sócio familiar. Solicitado pelo suposto pai quando este não tem dúvida da origem biológica do autor da ação, como também, a investigação de paternidade outro instrumento de inclusão sócio familiar do público infanto-juvenil, este por sua vez, beneficiada pelo avanço tecnológico no campo da genética, norteado por ações que 
são fundamentais para esclarecer as relações de parentesco, permitindo investigar a origem e a historicidade biológica do autor da ação.

O assistido pode buscar o Programa Pai Legal (PPL) das seguintes formas: podendo ser encaminhado pelos núcleos da defensoria espalhados pelos municípios do Estado do Pará, espontaneamente, anúncios e divulgações na mídia (rede sociais, jornais etc.), e/ou por informações de terceiros.

$O$ atendimento é realizado no prédio sede situado no bairro do Comércio em Belém. Chegando ao local o assistido (a) passa pelo Psicossocial/NAEFA (Núcleo especializado de atendimento a família) Térreo, onde é realizado seu cadastro no sistema de controle de processo jurídico, nesta fase averígua-se a documentação, onde a criança ou adolescente não possui pai registral, é necessário ter a filiação registrada apenas no nome de sua genitora, sendo esta condição imprescindível para realização do reconhecimento de paternidade do Programa Pai Legal.

O atendimento Psicossocial é desenvolvido através de ações oferecidas individuais e em grupo: criança, mãe, pai, suposto pai. Com o intuito de trabalhar a promoção do bem estar e com o compromisso de contribuir para a inclusão sócio familiar afetiva, com atuação acolhedora promovendo o acolhimento, a escuta qualificada, o diálogo, a orientação, observação e o encaminhamento que de acordo com a situação apresentada pelo suposto pai e/ou pai.

Podendo ser submetido ao exame de DNA quando o suposto pai apresenta na ocasião de seu atendimento dúvidas em relação à paternidade da criança ou adolescente em questão; ou pode ser encaminhado ao setor jurídico a fim de requerer o reconhecimento voluntário de paternidade, quando este não tem dúvidas a respeito da paternidade do filho.

Desta forma, o atendimento é gratuito seja este serviço solicitado através do exame de DNA e/ou pelo reconhecimento voluntário de paternidade. Este atendimento é realizado pela equipe técnica de atuação que é composta pelos defensores públicos, assistentes sociais, psicólogo, pedagogo, estagiários de serviço social e direito e 
técnicos de laboratório-patologia clínica. A análise do material coletado é realizada pelo Laboratório de Genética Humana da UFPA (Universidade Federal do Pará).

Em busca do consenso e a fim de contribuir para a redução dos conflitos que interferem diretamente no restabelecimento dos laços familiares, perante obstáculos que viabilizem a existência e manutenção das funções do grupo familiar e de cada membro, entende-se que é necessário criar condições que permitam a construção de estratégias para o enfrentamento e o empoderamento dos sujeitos sociais perante as dificuldades sociais e, de orientações que viabilizem assegurar a garantia de proteção ao filho e, estabelecer o liame de parentesco entre o filho e o pai.

De acordo com CAHALI (1996), nos dias de hoje manifesta-se uma preocupação ostensiva e decisiva com a verdade da paternidade, procurando afirmar a filiação para seu reconhecimento conforme a verdade real, biológica, com vistas a mais eficiente proteção da pessoa do filho (CAHALI, 1996, p.89). Entende-se que para o autor o reconhecimento de paternidade é um avanço substancial no direito do filho sem discriminar os que advêm de um matrimônio ou fora dela, todos tem os mesmos direitos.

\section{DISCUSSÕES E RESULTADOS}

O reconhecimento de paternidade realizado pela Defensoria, embora possa ser realizado por Ação Judicial de Investigação de Paternidade; Reconhecimento Voluntário; Reconhecimento Voluntário Mediante Comprovação (Exame de DNA); nos permite questionar sobre de que forma a inclusão sócio familiar é pensada no campo jurídico, considerando que a grande preocupação do Programa se encontra na descoberta de genitores, em sua maioria, o pai. Apesar de ser considerado como uma conquista no campo dos direitos, o Programa precisa avançar no sentido de propostas que possam pensar nas famílias, quem são? Como vivem? , bem como o significado de saber sobre a sua própria história.

Grande parte da população encontra-se abaixo da linha da pobreza, não dispondo de condições financeiras para custear o exame de DNA e nem arcar com despesas para 
requerer o reconhecimento voluntário no cartório, estes serviços, apesar de disponibilizados gratuitamente pelo Estado, precisam contemplar o conjunto de necessidades que estão para além da proposta de inclusão, mas que contribua para o alcance da sociabilidade das famílias, não apenas centralizando a mesma como única responsável por suas condições de vida.

Em 2005, o Programa Pai Legal obteve 3.530 casos até julho deste ano, disponibilizando o serviço de reconhecimento paterno espontâneo, ou por meio deteste de DNA. Na sua sistematização, o compartilhamento das formas de DNA entre a criança ou adolescente e o suposto pai permite estabelecer a paternidade com uma probabilidade maior ou igual a 99,9999\%. Por outro lado, quando não são compartilhadas, o suposto pai é excluído da possibilidade de ser o pai biológico, o que permite pensar aceca da proximidade entre inclusão e exclusão, tão contraditória no descarte de uma suposto genitor.

No que diz respeito a intervenção do assistente social, foi apreendido que este profissional realiza um atendimento, com comprometimento ético-político, competência profissional, atendendo as crianças e adolescentes vítimas de violência, visando à defesa e garantia de seus direitos e interesses em todos os níveis, utilizando os meios previstos na legislação vigente, particularmente os estabelecidos no Estatuto de Criança e do Adolescente.

As novas configurações de espaço profissional sinalizam a necessidade de um profissional capaz de apreender e traduzir no concreto, o real, o que se vivencia no cotidiano para construção de um fazer competente e conhecimento crítico, criativo e reflexivo, capaz de subsidiar as práticas quotidianas, dando embasamento, ético político, que assegurem direitos, democracia participativa e fortalecimento das potencialidades, pois, esses sujeitos de direitos não podem ser percebidos em parte.

Nesta perspectiva, Konder (1981) assegura que: "qualquer objeto que o homem possa perceber ou criar é parte de um todo. [...] Se não enxergamos o todo, podemos atribuir um valor exagerado a uma verdade limitada (transformando-a em mentira), prejudicando a nossa compreensão de uma verdade mais geral" (Konder, 1981:37), 
portanto, este profissional trabalha na integralidade ético política, com competência, suas ações metodológicas articulam entre teoria e prática que constituem sua autonomia profissional.

Desta maneira, compreende-se que o trabalho do assistente social perpassa pelo contraditório campo de ações assistencialistas, desenvolvendo um trabalho que busca a autonomia desses atores, seu desenvolvimento humano e social, suas potencialidades, fortalecimento das relações familiares e sociais. Apreende-se que cabe ao assistente social, profissional qualificado diagnosticar com diligência as distorções sociais, políticas, econômicas, morais e culturais, identificá-las para direcionar sua práxis de intervenção em razão do interesse superior da criança e do adolescente.

Contudo, percebe-se que perspectiva neoliberal, a participação da sociedade civil com o Estado, tem sido marcada por redução, ou seja, omissão dos direitos sociais, a desresponsabilização do Estado, pois, as políticas giram em torno dos interesses do capital. Durante o processo de observação, compreende-se que este profissional utiliza-se instrumentos de coleta de dados e técnicas de atendimento como: acolhimento, entrevista, análise de documento, orientação, observação e a visita domiciliar; os quais constituem instrumentos que somados ao saber técnico e teórico conformam um olhar diferenciado para o serviço social, que ao construir um projeto ético político profissional, se coloca ao lado das demandas da classe trabalhadora.

O atendimento é integral, humanizado de forma inclusiva, com alteridade e respeito humano, este profissional é habilitado e capacitado para apreender e perceber o outro na sua plenitude, buscando intervir nas expressões da questão social, no atendimento a crianças, adolescentes e suas famílias, particularmente aquelas que se encontram em situação de violência decorrente da ação ou omissão do estado.

As novas configurações de espaço profissional exigem do assistente social deverá apreender e traduzir no concreto, o real, o que se vivencia no cotidiano para construção de um fazer competente conhecimento crítico, criativo e reflexivo, capaz de subsidiar as práticas quotidianas, dando embasamento, ético político, que 
assegurem direitos, democracia participativa e fortalecimento das potencialidades, pois, esses sujeitos de direitos não podem ser percebidos em parte. Portanto, segundo Konder (1981) assegura que:

"qualquer objeto que o homem possa perceber ou criar é parte de um todo. [...] Se não enxergamos o todo, podemos atribuir um valor exagerado a uma verdade limitada (transformando-a em mentira), prejudicando a nossa compreensão de uma verdade mais geral" (Konder, 1981, p. 37).

Da mesma forma, o direito à convivência comunitária é significativo por facilitar o estabelecimento de novos vínculos e relações. A convivência comunitária deve ser efetivada pela garantia de acesso às famílias aos serviços oferecidos na comunidade, bem como por meio da participação das crianças e dos adolescentes em atividades oferecidas pela sociedade, tais como: lazer, esporte, religião e cultura. "Isso proporciona a convivência comunitária, evitando-se a alienação e inadequação à vida em sociedade" (SILVA; MELLO; AQUINO 2004, p. 234).

Embora haja o reconhecimento por parte do Estado da importância da família, verificamos que as ações governamentais têm sido insuficientes para proteger o núcleo familiar. [...] as políticas oficiais, voltadas para a família, quando existem, têm se mostrado inadequadas, pelo pouco investimento nas necessidades e demandas deste grupo, não oferecendo suporte básico para que possa cumprir de forma adequada suas funções (COELHO, 2002, p. 76).

Contudo, fica evidente que o cenário utilizado, embora proponha caminhos para nortear a busca pela autonomia, a inclusão social, familiar e comunitária, que segundo o ECA em seu art. 4ํㅡㄹ estabelece e apresenta como tripé de responsabilização o Estado, a sociedade civil e a família, a Defensoria ainda permanece no campo de uma proposta que vincula a descoberta de genitores como alcance da cidadania de plena, sobretudo, um pai, que expresso no sexo masculino carrega no marco da legalidade o trocadilho com o ser legal, um adjetivo que também qualifica positivamente. 


\section{CONSIDERAÇÕES FINAIS}

Este artigo apresentou como objetivo a análise do Programa Pai Legal como proposta de inclusão sócio familiar de crianças e adolescentes em Belém-PA. Nesse sentido, foi realizado o debate no campo dos direitos sociais no Brasil, considerando a legislação, código civil, o ECA e o Serviço Social. Dentro deste contexto, o presente estudo demonstrou que o Programa Pai Legal em Belém conta a participação de profissionais do Serviço Social junto ao Núcleo Especializado da Família, o qual tem como meta a inserção de profissionais qualificados para conciliar extrajudicialmente a questão relacionada aos direitos de família, em relação aos direitos de crianças e adolescentes que não possuem pai registral. No campo de ação do Serviço Social, observamos em sua gênese ações conservadoras, tradicionais, com princípios, valores e posturas norteadas pela doutrina social da igreja católica, referenciados por ações filantrópicas, de caridade e de ajuda. Nota-se que apesar de não significar o rompimento com o conservadorismo, a profissão tem enfrentado no cotidiano os impasses diante da perspectiva crítica que compreende os limites da defensoria na proposta de inclusão sócio familiar.

Essa intervenção profissional, apesar de voltada para o fortalecimento do convívio familiar, pois existem na realidade muitas situações complexas, as quais precisam da atuação de um profissional que possa intervir na realidade a partir da compreensão dos aspectos que rodeiam e norteiam as relações humanas e que provocam as situações de conflito, se defronta no limite de uma instituição que ainda concebe a inclusão como plena cidadania alcançada diante da descoberta de um genitor, sem identificar as origens da desigualdade social expressa muitas vezes nas famílias que demandam o atendimento de uma necessidade que tem custos financeiros elevados. A gratuidade, entende-se um direito social.

Além do mais, é preciso reconhecer as particularidades do Serviço Social na Defensoria Pública junto ao Programa Pai Legal e mostrou que a Defensoria Pública do Estado do Pará, por meio do referido programa tem procurado responder as demandas da sociedade paraense, em especial o segmento criança e adolescente, 
ao reconhecê-los como sujeitos de direitos, possibilitando assim, sua inserção social, familiar e comunitária, ainda que timidamente.

No entanto, está evidenciada a existência de inúmeras dificuldades que fazem com que tais direitos não sejam desfrutados em sua totalidade, pois estes não se efetivam de forma concreta. Desta maneira, apesar das ações da Defensoria Pública, direcionados a este segmento, seu limite permanece no campo da proposta de inclusão sócio familiar, ou seja, distanciado do viés que garante, em sua totalidade, a transformação da realidade social das famílias, concepção esta que transforma o assistente social, em um dos poucos profissionais que ainda defendem por concepções emancipatórias para a humanidade.

\section{REFERÊNCIAS}

ACACIO, Maria do Carmo. Orientações metodológicas para trabalhos acadêmicos. Belém: ESAMAZ, 2017.

BAPTISTA, D. M. T. O debate sobre o uso de técnicas qualitativas e quantitativas de pesquisa. In: MARTINELLI, Maria Lúcia. $O$ uso de abordagens qualitativas na pesquisa no Serviço Social: um instigante desafio. Pontifícia Universidade Católica de São Paulo - Programa de Estudo de Pós-graduação em Serviço Social, Núcleo Estudos e Pesquisa sobre Identidade. 2. ed. São Paulo: PUC/SP, 1994.

BRASIL. Constituição Federal de 1988. Constituição da República Federativa do Brasil.

\section{Lei Complementar no $\quad$ 80/90. Disponível em} http://www.planalto.gov.br/ccivil_03/Leis/LCP/lcp80.htm. Acesso em: 3 mar. 2018.

Lei no 8.069 de 13 de junho de 1990. Estatuto da Criança e do Adolescente. Vade Mecum Profissional e Acadêmico de Processo Civil, Estatuto da Criança e do Adolescente. I. Pinto, Antônio Luiz de Toledo. II. Wind, Márcia Cristina Vaz dos Santos. III. Céspedes, Lívia. 3. ed. atual. e ampl. São Paulo: Saraiva, 2007. 
CAHALI, Yussef. Reconhecimento do filho extramatrimonial. Rio de Janeiro: Livro de Estatutos Jurídicos, 1996.

CARDOSO, P. F. G. Ética e projetos profissionais: os diferentes caminhos do serviço social no Brasil. São Paulo: Papel Social, 2013.

COELHO, Virginia Paes. O trabalho da mulher, relações familiares e qualidade de vida. Serviço Social \& Sociedade. São Paulo: Cortez, no 71, p. 63-79, 2002.

DEFENSORIA PÚBLICA. Programa Pai legal. Disponível em: http://www.defensoria.pa.gov.br/E:|Livros\O princípio da dignidade da pessoa humana nas constituições do Brasil - Constitucional - Âmbito Jurídico.html. Acesso em: 22 jun. 2018.

FÁVERO, E.T; MELÃO, M.J.R.; JORGE, M.R.T. (Org). O Serviço Social e a Psicologia no Judiciário - construindo saberes, conquistando direitos. São Paulo: Cortez, 2005.

FORTI, V; GUERRA, Y. (org.). Projeto ético-político do Serviço Social: contribuições à sua crítica. Rio de Janeiro, Lúmen Júris, 2013.

FUZIWARA, Aurea Satomi. Contribuição do assistente social para a justiça na área da infância e da juventude: o laudo social e aplicação da lei - encontros e desencontros. 2006. Dissertação (Mestrado em Serviço Social) - Pontifícia Universidade Católica de São Paulo, São Paulo, 2006. Disponível em: http://www.sapientia.pucsp.br/tde_busca/arquivo.php?codArquivo=4432. Acesso em: 13 jun. de 2018.

GIL, Antônio Carlos. Como Elaborar Projetos de Pesquisa. 4. ed. São Paulo: Editora Atlas, p. 44,45, 2009.

IAMAMOTO, M. V. O Serviço Social na contemporaneidade: trabalho e formação profissional. 8. ed. São Paulo: Cortez, 2005. 
LAKATOS; E. M.; MARCONI; M. de A. Fundamentos de Metodologia Científica. São Paulo: Atlas, 1991.

MALTA, C. V. M; VERAS, M. M. Desproteção social de crianças e adolescentes na década de 90: persistência do atraso. In: VIII Encontro Nacional de Pesquisadores em Serviço Social. Juiz de Fora: ABEPSS-UFJF, 2002.

MINAYIO, M.C.S. Interdisciplinaridade: Uma questão de atravessar o saber, o poder e o mundo vivido. Ribeirão Preto: Vozes, v. 24, p. 70-77, 1992.

MINAYO, M.C.S. Pesquisa social: teoria, método e criatividade. Rio de Janeiro: Vozes, 1999.

NAZARETH, E.R. Mediação o Conflito e a Solução. São Paulo: Editora Arte Pau Brasil, 2009.

NETO, J. P. A construção do Projeto Ético-Político do Serviço Social. Serviço Social e Saúde, Brasília, CFESS/ABEPSS/ CEAD/ UnB, 2001.

OLIVEIRA, J.M. Leoni Lopes de. Nova lei de investigação de paternidade. 3. ed. Rio de Janeiro: Lumem Júris Ltda, 1995.

ORTIZ, F. G. O Serviço Social no Brasil: os fundamentos de sua imagem e da autonomia de seus agentes. Rio de Janeiro: E - papers, 2010.

SANTOS, B. de S. Porque é tão difícil construir uma teoria crítica. REVISTA Crítica de Ciências Sociais, n. 54, jun. 1999. Disponível em: http://www.boaventuradesousasantos.pt/pdfs/Porque e tao dificil construir teoria critica RCCS54.PDF. Acesso em: 22 abr. 2018.

SARLET, Ingo Wolfgang. Dignidade da Pessoa Humana e Direitos Fundamentais na Constituição Federal de 1988. 5. ed. Porto Alegre: Livraria do Advogado, 2007.

SILVA, Enid R. A.; MELLO, S. G. e AQUINO, L. M. C. Os abrigos para crianças e adolescentes e a promoção do direito à convivência familiar e comunitária. In: SILVA, 
Enid R. A. (Coord.). $O$ direito à convivência familiar e comunitária: os abrigos para crianças e adolescentes no Brasil. Brasília: IPEA/CONANDA, 2004. p. 209-242.

THURLER, Ana Liési. Paternidade e Deserção - Crianças sem Reconhecimento, Maternidades penalizadas pelo Sexismo. 2004. Tese (Doutorado em Sociologia) Universidade de Brasília, Brasília, 2004. Disponível em: http://www.scielo.br/scielo.php?script=sci_arttext\&pid=S0102-69922006000300007. Acesso em: 14 mai. 2018.

VIGNOLI, Maria Francisca Sales. A família como campo de atuação e investigação do serviço social brasileiro. 2007. Dissertação (Mestrado em Serviço Social) Pontifícia Universidade Católica de São Paulo, São Paulo, 2007. Disponível em: http://www.sapientia.pucsp.br/busca/arquivo.php?codArquivo=4806. Acesso em: 17 jan. 2018.

6. A alienação parental foi regulada pela Lei $n .-0$ 12.318/2010. Além da previsão legal, a proibição quanto à alienação parental tem fundamento constitucional no princípio da paternidade responsável (art. 226, § $7^{\circ}$ da CF/88).

Enviado: Fevereiro, 2019.

Aprovado: Julho, 2019. 